\author{
dr hab. Krzysztof Polok \\ Akademia Techniczno-Humanistyczna w Bielsku-Białej \\ Wydział Społeczno-Humanistyczny, Katedra Anglistyki \\ tel. 602574561 \\ e-mail: sworntran@interia.pl
}

\title{
TEACHING ENGLISH TO PRESCHOOL LEARNERS
}

\begin{abstract}
SUMMARY
The paper discusses the status quo and the would-be possibilities of kindergarten FL teaching. While analyzing the current forms and tendencies in teaching English to YL (Young Learners), it is postulated the only reliable form of teaching a FL to such groups of learners is to maximize their cognitive potential, so as to help them discover the language in an acquisitive way. Following the current research, it is suggested that the challenge-like conditions that are naturally formed to $\mathrm{YL}$ in the case of learning their mother tongue (MT) are to be extended so as to help them learn a FL as well. The final part of the paper provides a discussion over the current research results that refer to the paper topic.
\end{abstract}

Key words: cognition, FL learning/teaching, language acquisition, YL, the immersion method, kindergarten education

\section{STRESZCZENIE}

\section{Przedszkolna nauka języka angielskiego}

W pracy omówiono stan obecny oraz możliwe drogi rozwoju istotnych zagadnień nauczania języka docelowego (drugiego) w odniesieniu do dzieci przedszkolnych. Na bazie analizy obecnych form oraz tendencji, jak również badań przeprowadzonych ostatnio w tym względzie, dotyczących nauki języka angielskiego w przedszkolach, został wysunięty postulat takiego połączenia pracy nad językiem angielskim w odniesieniu do tych grup uczniów, aby możliwie maksymalnie otworzyć ich aparat kognitywny na względnie naturalne możliwości zaznajamia- 
nia się z językiem docelowym. Końcowa część artykułu zawiera dyskusję uzyskanych wyników badawczych i wskazuje, iż nie wszystkie z badanych dzieci były w stanie samorzutnie przetworzyć warunki rzeczywistości nadanej (np. przez nauczyciela) na warunki rzeczywistości realnej (czyli osobistej komunikacji językowej).

Słowa kluczowe: kognicja, nauka/nauczanie języka obcego, przyswajanie języka, metoda immersyjna, nauczanie przedszkolne

The fact that English was recognized as a global language resulted in the appearance of many different ideas, generally focusing upon the elaboration of the educational techniques that would help the learners become its proficient users in as simple and not time-consuming way as possible. Apart from the ideas that should help discover the language by adolescent and/or adult learners, there are also quite a few suggestions on how to teach English to quite young language learners. Basing on the past research it is believed the younger are the learners, the more efficient is the very process of language education. One of the goals of this paper is to critically assess the efforts that can be found in the field of kindergarten FL teaching as well as to suggest a way that seems to be the most interesting, mostly because of its possibilities to save and secure the interests of YL. In this way, what is to be analyzed first of all are the principal features of YL psycho-pedagogical approach to be followed by a form of meta-analysis of the attempts undertaken to create YL-friendly FL learning conditions.

\section{Who are young learners?}

Technically, YL are defined as a group of children who have been subjected to the planned learning process at the age not reaching the age of their formal adolescence. Psychologically, however, the definition of YL is far more difficult as one has to take into account no only the age, but also the learners' level of learning credibility. A handy definition by Sarah Phillips ${ }^{1}$ turns the readers' attention onto the factors that “(...) influence children's maturity: for example, their culture, their environment (city or rural), their sex, the expectations of their peers and parents". Subsequently, the author remarks that any teacher, while making up her mind to introduce certain selected types of language learning activities into the classroom, should be well aware of these differences, remembering that both the intellectual and the psychological development of any child always goes

$1 \quad$ S. Phillips, Young Learners, Oxford 1993, s. 5. 
individually. Lisbeth Ytreberg ${ }^{2}$ lists a set of characteristic features of YL, stating that they /1/ tend to use language skills not being quite aware of the activity; /2/ may have problems with clear distinguishing between the real and the fictitious world (what might be difficult for the teacher, as she may not always be able to cope with this particular feature); /3/ clearly prefer holistic forms of education; /4/ are unwilling to learn alone; /5/ have short attention span; and, finally, /6/ learn effectively when they are fully involved in the play-like activity. Finally, Magdalena Szpotowicz and Małgorzata Szulc-Kurpaska ${ }^{3}$ present another list, this time based upon the findings of Edelenbos, Johnstone and Kurbanek ${ }^{4}$, stressing the learning environment YL are expected to take their FL education ("which supports their progress and allows for [further] language continuation"), indicating the intrinsic form of FL motivation to be mostly observed in such a group of learners, informing about the individual nature of such education, suggesting the application of a number of imagination-developing techniques and procedures (story-telling, staging, TPR-like forms of language deliverance) and, last but not least, urging to remember that the attitude to language learning found in YL is not stable, but subject to continuous development.

All these remarks seem to indicate a number of important steps that must be paid attention to when any YL language education, kindergarten language education included, is being planned. First of all, one has to remember that such learners are clearly different from the ones normally found in the classes filled with adolescent learners and that any classroom-like education for YL has to be planned with caution. As these learners may have problems with planned and repetitive forms of education, any form of language deliverance has to include this planned language-revision section into the language handling process. Apart from that, as the element of YL pro-language motivation is of intrinsic nature, they have to be fully involved into the FL activities, so as to be allowed to discover the language themselves instead of be given the structures and/or lexical information to be memorized by heart. This is why active forms of learners' language involvement are so strongly recommended. This is also why such forms as staging-based language education, for example, are of interest here. Learners must be given a chance to feel personally connected with the language, as any such individual connection resembles (reveals) various forms of holistic teaching. One has to remember that what matters in any form of language education is the birth and gradual development of a feeling that the language that is being

\footnotetext{
L. Ytreberg, W. Scott, Teaching English to Children, New York 1990, s. 1.

M. Szpotowicz, M. Szulc-Kurpaska, Teaching English to Young Learners, Warszawa 2012, s. 12.

http://ec.europa.eu/languages/policy/language-policy/documents/young_en.pdf, [online], dostęp: 15.01.2015.
} 
discovered and used is not for the sake of satisfying the teacher (or the parents), but for far more pragmatic and down-to-the-earth purposes, one of them being communication. However, as the notion of communication is a fairly abstract one, and hardly any kindergarten learner is able to embrace it cognitively, what must be implemented is a notion that the language phrases just learned are for immediate use - the use that is to be evidenced either in the form of staging or some other type of kinaesthetic performance.

This is where one more important segment of YL language education must not be overlooked - this is the aspect of a language lesson creative tissue. Mostly due to the fact that YL have a short memory span they are not able to concentrate upon one topic for a longer period of time, on condition they have not been truly involved in the topic. This aspect of the necessity of the learners' personal involvement in the lesson makes the teachers' work particularly demanding as they are expected to go on functioning upon the creative level of the learners' reasoning, making the teaching/learning time as holistic as possible. The learners have to be given a chance to discover the real use of the language ('real', in this sense, means any other, but not artificial), as any pretence of artificiality detected by the learners immediately changes the process of FL learning into a form of language-like education. In other words, as YL are recognized to be very sensitive creatures from the psychological point of view they will immediately discover false tones in the lesson texture and feeling the teacher is not truly fair with them, change their attitude to the lesson goals; losing interest in the activities planned by the teacher is, in these circumstances, the meekest form of their protest. But even this one is sufficient enough to recognize the whole teaching process (a lesson) as not correctly planned.

\section{Teaching a FL - what we know and what we have to remember about}

Generally, any process of FL education is expected to include three clearly delineated phases of the learner's contact with the language called, respectively, input, intake and output. Out of these three, the first one is usually devoted to the presentation of the material to be worked upon, the second one is expected to help the learners discover these input elements that can be considered as important for them, whereas in the third one the learners are thought to be able to make their individual use of the information just delivered, having previously connected them intrinsically with the old, already stored, bulk of information. In this way the phase of output is the phase during which the learners are not only expected to demonstrate how far they have learned the 
new pieces of knowledge, but also how neatly they have been able to connect them with the knowledge already internalized. As one of the quite unwelcome human memory-connected tendencies is the one of throwing out these elements of stored material that have been subconsciously recognized as useless, in order to retain all (or at least as much as could be) FL-connected segments in the memory the didactic activity of continual, periodically effected, revising character must be introduced. The learners' memory has to be reminded that all the already stored elements have to be neatly kept and carefully handled, so as to be effortlessly retrieved when needed.

The working activities of the human memory, and especially the ones that are connected with FL education, have become one of the most puzzling issues to be solved by science. It is the neurosciences that have recently offered a solution to this question; it appears that learning depends on both the number of synaptic connections found between brain cells, and the growing amount of repetitive situations that can be found inside human brain. What's more, as James Zull, the author of the theory claims, the human brain is always ready to produce new and still new synaptic connections between brain cells, in this way producing new segments of knowledge ${ }^{5}$. Partly basing on Zull's hypothesis, Eric Jensen ${ }^{6}$ lists the seven conditions necessary for effective learning, FL learning included, stressing /1/ attentive engagement in the process of FL discovery; /2/ constant revisions of the knowledge already stored; /3/ the quantity of the input, its capacity and chunk size; /4/ the learning hygiene (the timing and learning intervals); /5/ the level of coherence (focusing upon the models, relevance and the prior knowledge); /6/ reception of support and professional feedback in the process of one's error correction; and /7/ the scope of relative emotional comfort (the scope of being dependent upon somebody superior) in the book of his. Additionally, apart from the learning facts already mentioned, it has been found that human mind learns best in the conditions of a challenge of either economical, or physical or social type $^{7}$. The final observation partly evidences not only Lew Wygotski's theory about the social and cultural character of language, but also his claim concerning the existence of a zone of proximal development as important in the process of language development of a young learner ${ }^{8}$.

All the information presented so far in this section indicate that the process of learning closely follows the ideas found in the constructionist theories of

5 J. Zull, The Art of Changing the Brain; Enriching the Practice of Teaching by Exploring the Practice of Learning, Sterling 2006, s. 45.

6 E. Jensen, Teaching with the Brain in Mind, Alexandria 2005, s. 66.

7 J. Zull, op. cit., s. 79.

8 L. Wygotski, Narzędzie i znak w rozwoju dziecka, Warszawa 2006 [1978], s. 78. 
learning, which assume that what plays primary function in any process of FL education are meaningful contacts, as it is these meaningful contacts that evoke the phenomenon of interaction. Therefore, the theories stress human individual efforts to construct their own new concepts based on the previous knowledge and connected to the real situations a human is actually taking part in. In this way, the process of learning is conditioned by means of the reception and the analysis of new information, its comparison with the past (experience-based) knowledge, its subsequent process of adaptation and a sensible adjustment to the scope of knowledge about the world internalized so far.

These constructivist theories of learning split into three types; the first of them are cognitive constructivist issues that focus upon individual learners, stressing that $/ 1 /$ it is the learner that should find the meaning, rules, information etc. of a concept; $/ 2$ / reproductive learning is also important as it helps internalize the knowledge; / $3 /$ the process of learning depends upon the student him/ herself, i.e. the degree of his/her autonomy and initiative in designing his/her conceptual hypotheses.

In contrast to such cognitive constructivist theories, the second constructivist branch, i.e. social constructivism, emphasises the social dimension of the learning process, claiming that the two pre-conditioned segments in the process of one's learning are social interaction and culture (cf. Wygotski, 2006[1978]).

Finally, there is pedagogical constructivism, which fuses the two approaches specified above, in this way joining the issues stressed upon in cognitive and social constructivist domains.

\section{How could we find the theory being anchored in the practice?}

Obviously, the process of YL language education must observe all the theoretical issues presented above. First of all, we have to remember that it is the learners that are expected to store the material delivered to them and that they should be made aware of the fact that they can do with the linguistic data they own whatever they wish, as it is the only instrument they have to produce any message they want to in a given moment of time. This, however, seemingly simple, idea appears to be an approach many YL are difficult to find out, especially, if they have not been given a chance to experience a situation they got used to when discovering the potential of their mother tongue. The process of interaction, so important in the formation of a communicational framework, appears to become the most important educational activity a YL has to experience if only his/her L2 lexicon is to be effectively constructed. In other words, the learners have to be convinced that their language is not being learned to suit some artificial, albeit 
temporarily important reasons, such as singing a foreign song or staging out a story in a foreign language, but that the language they discover can (and ought to) be used for far more important goals, such as a description of their out-oflanguage reality, for example.

Definitely, what matters in any FL education is the purpose; the learners (all of them) have be become aware of the reasons why they are expected to learn some (usually selected) foreign phrases. In the case they are informed they need a FL to sing a song, clap their hands while singing it, or perform some other movements they will readily do that and have a lot of fun while performing all these activities. But, as their task was to learn a limited number of expressions so as to be able to perform a clearly specified activity, one should not hope they would retain all the phrases in their mind, so as to use them to serve their own, individual, subjective purposes. In the moment, they have stopped repeating the song, the words and phrases just memorized will slowly but unmistakably disappear. As it seems, memorizing a foreign song, or the words to stage out a story, are only the beginning elements of a very complicated (and very well planned) process of YL foreign language education.

What the learners need first of all to learn a FL is their exposition onto the language to be mastered by them. In case of artificial FL education, i.e. the one that is to be observed in plenty of Polish kindergartens, a plan of interactive activities is to be elaborated in such a way that the young learners are highly exposed onto the structures and the cultural heritage of the language learned by them. The three conditions of the cognitive constructivist branch have to be wisely introduced into the FL teaching plan, so that the learners were able to experience their ability to produce a meaningful message in the language just discovered.

It is generally known that all the activities used during FL education processing can be split into productive and reproductive ones. The productive activities are the ones that help the learners re-apply the language learned for whatever other purpose; in contrast to these, reproductive activities are those that allow the learners to reproduce the language learned in the situations which had necessitated the learning process. In respect to YL foreign language education, productive activities could be such activities as craft activities, or board or action games, as all of them expect the children learners to make use of the structures and expressions learned in some other, relative, purpose. At the same time, such commonly observed FL learning activities as singing a song, action rhymes, 'listen and show' activities or action songs, as well as staging out a story/play clearly fall into the group of reproductive activities, as their principal educational purpose is to learn the expressions to reproduce a song (in any way) or act out a story/play. Later on we will try to evidence the two facts and present their relative 
influence on the quality and the process of foreign language proficiency to be observed in the case of YL.

Obviously, there is nothing wrong in the over-application of reproductive activities (after all they do help the learners remember the phrases) on condition the teachers have provided the learners with appropriate meanings of the phrases memorized by them. However, in the case, the learners have been provided a form of a mental shortcut (such as that the phrase A means ' $a$ ' in the leaners' mother tongue), in many of these unexperienced linguistically learners an idea (a false one) of language identity has been planted. A stance that all FL learners ought to be given a chance to discover the power of a context is the only stance that is to be effectively observed (and followed) during the whole process of YL linguistic education.

The importance of teaching the power of context in FL education must not be overlooked and the fact that the receivers of the linguistic information are YL is not to be considered as an excuse. There are very strong arguments for such an approach to YL language education. The first of them is the fact that they (or at least their parents) want to know the communicative face of the language learned by them. Such an approach means rising a claim that the final result of the children's linguistic activity is a form of relative fluency within the language learned by them.

The second (equally important) aspect is an assumption that it is the learners themselves who ought to be able to discover that they have to use the language for whatever reason to become proficient in it. A situation in which the learners are offered a bunch of context-less expressions must result in the discovery that what is called a language differs from the first language they have learned, mostly because the first language (their mother tongue) is closely bound with a context whereas the second language is not (even if they are not able to openly verbalize the difference, they can subconsciously feel it).

Additionally, a claim that they still have time to discover the fact that both their mother tongue and a foreign language are equivalent to each other does not explain anything; assuming that they re-formulate their opinions about a language later on is similar to walking on thin ice, as in both cases the result of such an activity is uncertain. In the case of a foreign language much depends on the future teachers who may not always be able to convert the learners onto the correct form of seeing the language. Apart from that, it is generally known that what matters in the description of the world is the amount of slowly (but steadily) accumulated experience, which can always be modified, but what is very often modified purposefully are the principal ideas that have to be changed so as to straighten the general picture of human existence - many things recognized as 
trifling (such as what is a language and how it correlates with the mother tongue, for example), are often reconstructed by chance.

One more issue to be discussed is the one concerning YL involvement in the process of FL education. It is here where Wygotski's theories have to be taken into account. Both the theory of cultural and social influence on the mental development of children and the one stressing the fact that it is due to the functioning in the challenge-focusing environment that children's mental development is truly benefitted are to be seriously analysed when YL education, language education included, is to be considered.

The first aspect that is to be looked into is the way language is being internalized; Wygotski claims that it is the social environment that is to be recognized as the basic condition for one's language development; we speak the language we are exposed to, all the peculiar characteristic features of this form of language included ${ }^{9}$. What's more, while learning the language (or rather a special form of description of the world we are able to experience around us) we are given a pattern of description and definition of the world - this is the way one should be able to comment on the world as well as to produce messages about anything of interest in it. From now on - we can be able to structure the world the way the language learned will let us do that. From now on the language will become the basic instrument informing the external world about our ability to function in it and to shape it according to our decisions. From now on we will become the legitimate users of the culture we have been born in, what means we are given a right to mould the culture (and the language) we have inherited. However, at the same time, it is here where all the problems with the second language begin.

Following the weaker version of the language relativity hypothesis by Edward Sapir and Benjamin L. Whorf, it is a culture (as well as all native depositors of the culture) that are primarily responsible for the formation, growth and further development of a language ${ }^{10}$. As there are no two identical cultures, there could be no two identical languages. On the other hand, mostly because cultures are not being developed far away from one another, there are not too discrepant approaches to the all-over description of the external world as the cultures (and the languages, which are the instruments formed to describe them) borrow the applicable approaches from one another. Thus anybody, wishing to define the world in some other language than their native, is expected to discover the "official" approach (as well as the forms of linguistic description of the out-of-

9 Ibidem, s. 83.

10 B. Whorf, Language, Thought, and Reality: Selected Writings of Benjamin Lee Whorf, John B. Carroll (red.), Chicago 1956. 
language reality) a given culture/nation has accepted as legitimate descriptors of the world. In other words, roughly speaking, one has to do lot of comparative work based upon a discovery of similar, as well as different, forms of description of the world that exist in the two compared (i.e. learned) languages/cultures. Actually, such work can be done only after one has been exposed onto the second language for the period of time long enough to experience ("notice") the intralinguistic differences.

It is here where the second Wygotski's claim is to be taken into consideration. ZPD (zone of proximal development) was defined as a mental situation when due to having placed a child in more demanding (from the intellectual point of view) conditions - a child is forced to make use of the mental capabilities that are normally not needed to solve an experience-requiring situation. It is here where the external situation children have found themselves in forced them to challenge the situation and find a way out - the way that would help them correctly define themselves in the new, demanding, external conditions. Richard Rodriguez ${ }^{11}$ describes a situation he experienced himself in his youth when he appeared in the US for the first time and discovered that the language he had used so far suddenly appeared to be useless (what forced him to learn the new language as far as possible). It is this external situation that actually challenged him and forced him to do something he had never supposed to be able to - to understand that the language used to communicate primarily depends on the territory of its (legitimate) use, as well as that there can be any language good enough to form a message.

Obviously, Rodriguez was in a favourite position, as the level of his exposition onto the second language was strikingly different from the one L2 learners participating in the artificial form of learning a new language are. Unlike him, the artificial learners of L2 are not truly caught between two languages, as the second language they are expected to remain inside in most cases surrounds them within a strictly pre-defined period of time. As the periods of time the learners are to be exposed to the target language have been strictly described, the questions concerning the intensity of their exposition as well as the one of the level of its practical usefulness remain within the scope of a lesson design planned by the teacher. Having assumed that forcing an L2 learner to remain within the sphere of effective influence of the target language can described as a challenging situation (because of many reasons), this is from where the issues of planned L2 exposition have to be studied. What has to be analysed are the

11 R. Rodriguez, Caught between two languages, [w:] Language Awareness, P. Eschholz, A. Rosa, V. Clark (red.), New York 1990, s. 97. 
following questions: / 1 / the amount of the target language effectively used by L2 teachers during their contacts with the learners (kindergarten learners included); $/ 2 /$ the amount of challenge-centred interaction-focusing situations offered by L2 teachers to their learners; /3/ the configuration of the preferred teacher roles facilitating the very process of learners' L2 contacts; and finally /4/ the ways L2 is used in a teachable way (i.e. the learners are able to draw their implicit conclusions from the practical situations). This is where the current research is expected to provide much more information.

\section{What does the research inform us about?}

The research data presented in the paper mostly come from the two interesting BA dissertations concerning the external conditions of FL education commonly observed in Poland. The first research is the one done by Aleksandra Laszczak ${ }^{12}$ and concerns the easy-to-discover differences between the L2 (English) learning environment in the two UE countries - Poland and Denmark. The second one, done by Martyna Manowska ${ }^{13}$, refers to, generally speaking, the approaches, lesson designs and techniques, generally preferred by Polish and native (English) teachers employed in Polish kindergartens.

Laszczak, while following her ERASMUS scholarship abroad (in Denmark), decided to investigate possible differences that can occur between Polish and Danish systems of FL primary school education. Assuming that the quality of L2 language environment does influence the level of its internalization, she investigated the most popular forms of FL deliverance to be observed in the two countries mentioned in the title of her BA dissertation. As one of the principal incentives of her research was a commonly observed assertion that the Scandinavian people are - generally speaking - more fluent in English than the inhabitants of some other (mostly middle) European countries, she decided to find out how far this stereotypical opinion goes on and - in case it were verified as correct - what were the reasons for its appearance. In her research, based upon filmed lessons delivered to the learners of English in the two researched countries, she not only discovered the basic differences between the Polish and the Danish systems of FL education, but also many differences in the general approach to the very idea of FL education between Polish and Danish FL (English) teachers.

12 A. Laszczak, Learning Environment - Differences Between Poland and Denmark., Unpublished BA dissertation ATH, Bielsko-Biała 2014.

13 M. Manowska, Stressing Pre-school Children FL (English) Effectiveness. A Comparative Study, Unpublished BA dissertation ATH, Bielsko-Biała 2014. 
Some of her findings were, for example, that the teacher roles preferred in Poland were the assessing ones (in contrast to Denmark, where the lesson helper roles prevailed) and that the a mounts of target language exposition in the two compared countries differed drastically (Poland - up to 5-7 min/lesson; Denmark - up to $97 \%$ of the lesson).

The principal goal of Manowska's research (2014) was to discover the scope of FL (English) effectiveness in Polish kindergartens, when the lessons are being delivered either by Polish, or foreign teachers. In this way, having adopted the suggestions by Anne Malamah-Thomas ${ }^{14}$ (1988, 79ff), she researched the importance of L2 lesson approach upon the resulting quality of FL proficiency in case the principal target of the FL educational activity were kindergarten learners.. The discoveries found by her show that the general approach, where the nature of the FL educational procedures remains of key importance, does not perform the principal function in the very process of FL education and that it is the internal, individually-handled understanding of what FL education is, what matters in the very process of FL education.

Both researches illustrate basic differences between a number of theoreticallygrounded assumptions and the reality of FL education. Laszczak's research shows that the target language exposition among elementary (and, supposedly, kindergarten learners) is far from average even, and that the ruling language in Polish kindergartens is the mother tongue; additionally, it shows that the roles the researched teachers preferred were of evaluative (and not educational) nature, what had to influence the general quality of FL education in the schools they taught.

Additionally, Manowska's findings show that many (mostly Polish) kindergarten teachers are, generally speaking, not fully aware of the final results of their work, believing that what they are doing are, hopefully, the beginnings only and that their learners would have plenty of time to reconsider the nature of the language they have got in touch with. This is why - as the research evidences they clearly prefer reproductive rather than productive techniques, in many cases treating the lessons as the learners' first approach to the target language, the one that should result in their growth of interest (and motivation) in it. Such a stance must (and does) result in the learners' problems to discover the inner nature of the language they are to learn, as well as the formation of a false approach forcing them to believe that the FL they have got in touch with is nothing serious, just a form of killing their time, as they have to do something while in a kindergarten, or else they would bore themselves to death (is it really possible for a kid, so anxious

14 A. Malamah-Thomas, Classroom Interaction, Oxford 1988, s. 79. 
to discover who $s /$ he is and where s/he is ???). In this way, language education has become one of the obligations (and not necessities) and is expected to be considered like this in future. Having understood the conditions formed in this way, is it really so difficult to predict that - in future - many learners (not truly forced by the external conditions) would still keep considering FL lessons as an unwelcome obligation rather than a possibility to re-describe the out-of-language reality in accordance to the expectations of the target language?

\section{Conclusions}

Having presented the main issues of the problem, what is usually required are a few sentences of conclusive nature that would indicate the principal aspects concerning the nature of the activities (and forms of more-or-less planned behaviour) observed within the area of interest. First of all, the very approach to kindergarten (English) education is to be assessed. Generally, the approach seems to be a care-free one; it is hoped the learners would be able to re-establish their attitude to FL education once they grow older. This is why fun-evoking, but repetitive activities are being preferred by FL non-native kindergarten teachers. An approach like this must (and does) result in the appearance of the attitude that does not foster the process of FL education, pushing the very contacts with the FL aside and considering them as a form of obligatory kindergarten activities (and not a possibility to help the learners re-organize their place in the world). A stance like this clearly goes against common sense regulations that lets many people (Wygotsky included) trust in the inner capabilities children have that would help them discover the sense and the necessity of learning ("noticing") the ways of world descriptions that clearly differ, the ones approved of in the country of their origin.

Additionally, the process of FL education must be based upon an approach that would help kindergarten learners discover (and accept) the necessity of becoming competent in the target language. Any approach like this must accept the amount of FL exposition upon the target language. As the time a non-native language learner becomes able to notice a difference between his/her mother tongue and the target language remains an individual feature of the learner, a FL teacher must provide the learners with the amount of time long enough to help them find out the would-be differences in the description of the external world. In order to do that, the assessing approach, commonly met among many Polish teachers, has to be replaced by the one accepting foreign lesson participants as the learners of the language in question. Having assumed an approach like this would help both the learners and the teachers understand (or, at least, discover) 
the complex nature of the problem, labelled as FL (English) kindergarten teaching. In this way, FL (English) kindergarten teaching would retain its well-deserved position and its technical aspects would be given a chance to be recognized what they are. Additionally, this form of language education, when deprived of a number of its ill-deserved myths, would be admitted its appropriate place in the hierarchy of FL education processes - the place it has actually occupied from the very beginning.

\section{References}

Jensen E., Teaching with the Brain in Mind, Alexandria 2005.

Laszczak A., Learning Environment - Differences Between Poland and Denmark, Unpublished bachelor dissertation ATH, Bielsko-Biała 2014.

Malamah-Thomas A., Classroom Interaction, Oxford 1988.

Manowska M., Stressing Pre-school Children FL (English) Effectiveness. A Comparative Study, Unpublished BA dissertation ATH, Bielsko-Biała 2014.

Phillips S., Young Learners, Oxford 1993.

Rodriguez R., Caught between two languages, [w:] Language Awareness, P. Eschholz, A. Rosa, V. Clark (red.), New York 1990.

Szpotowicz M., Szulc-Kurpaska M., Teaching English to Young Learners, Warszawa 2012.

Whorf B., Language, Thought, and Reality: Selected Writings of Benjamin Lee Whorf, John B. Carroll (red.), Chicago 1956.

Wygotski L., Myślenie i znak w rozwoju dziecka, Warszawa 2006.

Ytreberg L., Scott W., Teaching English to Children, New York 1990.

Zull J., The Art of Changing the Brain; Enriching the Practice of Teaching by Exploring the Practice of Learning, Stylus 2006.

http://ec.europa.eu/languages/policy/language-policy/documents/young_en.pdf, [online], dostęp: 15.01.2015. 